\title{
Implementing Islamic law to protect the environment: insights from Singapore, Malaysia, and Indonesia
}

\author{
Shazny Ramlan* \\ Research Assistant, Centre for Asian Legal Studies (CALS), National University of Singapore Faculty \\ of Law
}

Religious codes possess social control effects that can potentially change the behaviour of their adherents towards becoming pro-environment. In the case of Islam, Muslim-majority states since the time of the Prophet Muhammad have implemented Islamic environmental law to this effect. Unfortunately, accounts of its implementation today in the legal literature are scant, thereby requiring fresh insights that consider changes in the application of Islamic law in modern states. Generally, this article observes that the implementation of Islamic environmental law today takes two forms: first, implementation through constitutions; and, second, implementation through non-binding religio-legal instruments. Focusing on the second form, application in Singapore, Malaysia, and Indonesia is analysed and evaluated. In these three Southeast Asian states non-binding religious rulings (fatwa) and mosque sermons (khutbah) have been used to implement Islamic environmental law. There are two key factors which contribute to ensuring that these non-binding instruments achieve their social control objectives: first, local legal and political contexts shaped by religion-state relations that help their implementation and legitimation; and, second, the pursuit of post-fatwa/khutbah follow-up action by religious authorities to put Islamic environmental law into actual practice.

Keywords: comparative environmental law, Islamic law, law and religion, Southeast Asia

\section{INTRODUCTION}

In environmental law, there exist sources of normativity that aim to fulfil objectives similar to environmental statutes. Most contain somewhat clear environmental rules and mechanisms for social control essential for ensuring compliance with those rules. The most promising of these sources, arguably, is religion. ${ }^{1}$ Most of the world's population, around 84 percent, follows a religion and abides by prescribed religious

* The author thanks CALS for its support and funding of a presentation of a draft of this Article at the Socio-Legal Studies Association (SLSA) 2019 Conference held from 3-5 April at the University of Leeds. The author also thanks attendees of the CALS Researchers Seminar held on 29 November 2018 for their comments on an earlier version of the Article. Finally, the author thanks Paul Reddish (Department of Psychology, National University of Singapore), and Kimin Eom (School of Social Sciences, Singapore Management University), for their research assistance on the psychology of religion and experimental social psychology of pro-environment behaviour respectively. All errors remain mine.

1. Émile Durkheim, The Elementary Forms of Religious Life (Joseph W Swain tr, George Allen \& Unwin Ltd, 1915) 386. 
codes in their daily lives. ${ }^{2}$ Despite secular governance in most states, these codes contain rules of conduct that are generally enforced as social rules; and where the state establishes religious institutions, these rules may be enforced by a religious court or tribunal. ${ }^{3}$ Additionally, religious codes possess similar social control effects as that expected of state laws, and thus, can potentially change the behaviour of their adherents towards becoming pro-environment. ${ }^{4}$

One may argue that Islam best exhibits these features as compared to other religions because of the continued operation of Islamic law today at both state and societal levels. Most Muslim-majority countries adopt legislation to administer Islamic affairs and establish institutions for implementing Islamic law. Some go further to give Islam constitutional status, either enshrining it as the state religion, or as a source of law and/or guiding principles of governance. ${ }^{5}$ More importantly, the Islamic religion contains clear rules on environmental protection, explicitly imposing duties and obligations on humanity. Over 300 Quranic verses deal directly with the environment, and environmental protection laws have been implemented based on Islamic doctrine since the time of the Prophet Muhammad. ${ }^{6}$ Hence, environmental protection has always been part of the Shari a. ${ }^{7}$

The last extensive study on the implementation of Islamic environmental law ${ }^{8}$ in Muslim-majority states was published almost six decades ago - albeit in the specific context of water governance - suggesting its gradual devolution to localities as states adopt modern environmental statutes. ${ }^{9}$ How Islamic norms are implemented today - defined in this Article as 'establishing law and putting them into actual practice'

2. Pew Research Centre's Forum for Religion and Public Life, 'The Changing Global Religious Landscape' (5 April 2017) <www.pewforum.org/2017/04/05/the-changing-global-religious-land scape/> accessed 5 August 2020.

3. See Wolfgang Fikentscher, Law and Anthropology (2nd edn, CH Beck, 2016) 106. Fikentscher distinguished between social norm 'administration' and religious law 'enforcement', positing that 'religion requires an authorized entity which administers norms, but - except for religious laws - sanctions are absent'.

4. Roscoe Pound, Social Control Through Law (Yale University Press, 1942) 18-19; Edward A Ross, 'Social Control V. Religion' (1986) 2 American Journal of Sociology 433.

5. See Christie S Warren, 'Constitutions and Islamic Law' in Oxford Research Encyclopedia of Religion (Oxford University Press, 2017) <https://oxfordre.com/religion/view/10.1093/acrefore/ 9780199340378.001.0001/acrefore-9780199340378-e-96> accessed 5 August 2020.

6. Omar A Bakhashab, 'Islamic Law and the Environment: Some Basic Principles' (1988) 3 Arab Law Quarterly 287; Abubakr A Bagader et al, Environmental Protection in Islam (2nd edn, IUCN, 1994); Mohammad Assayed Jamil, A Study on Environmental Issues with Reference to the Qur'an and the Sunna (ISESCO, 1999); David Livingston, 'Intra-Muslim Debates on Ecology: Is Shari'a Still Relevant?' (2012) 16 Worldviews: Global Religions, Culture \& Ecology 218; Mohamed A 'Arafa, 'Islamic Policy of Environmental Conservation: 1,500 Years Old - Yet Thoroughly Modern' (2014) 16 European Journal of Legal Reform 465; Geoffrey E Roughton, 'The Ancient and the Modern: Environmental Law and Governance in Islam' (2007) 32 Columbia Journal of Environmental Law 99.

7. The meaning of the Shari a goes beyond our conventional understanding of law. As Weiss describes it, the Shari a 'includes norms beyond those that constitute law in the strict sense, it is incorrect to equate Shari 'a and law simpliciter as is often done. On the other hand, law is clearly part of the Shari 'a, in Muslim thinking, and must always be understood as such.' Bernard G Weiss, The Spirit of Islamic Law (University of Georgia Press, 1998) 8.

8. This term is borrowed from Anna Gade, whom the author believes was the first to coin the term in the literature: Anna M Gade, 'Islamic Law and the Environment in Indonesia: Fatwa and Da'wa' (2015) 19 Worldviews: Global Religions, Culture and Ecology 161, 162.

9. Dante A Caponera, Water Laws in Moslem Countries (FAO, 1954). 
- is largely undocumented. Available legal ${ }^{10}$ literature on this subject-matter is largely theoretical in scope and does not satisfactorily account for contemporary approaches to its implementation. ${ }^{11}$ Nevertheless, it is observed that the implementation of Islamic environmental law in Muslim-majority states today takes two forms. The first is implementation through constitutions. That, by enshrining the Islamic religion as a source of constitutional norms, an argument can be made that all laws enacted by the state including environmental statutes - are necessarily 'Shari 'a-compliant' and embody Islamic environmental norms. ${ }^{12}$ The second is implementation through non-binding religio-legal instruments. These instruments are typically produced by authoritative religious bodies and in the religious sense establish and impose 'legal' duties, but are practically non-binding under domestic law. In this particular approach, enforcement of those duties relies on local Muslim communities themselves.

This article accounts for the second form of implementation, and to that end, analyses and evaluates its application in three jurisdictions: Singapore, Malaysia, and Indonesia. In these Southeast Asian countries with significant Muslim populations, ${ }^{13}$ non-binding instruments in the form of religious rulings (fatwa) and mosque sermons (khutbah) have been used to implement Islamic environmental law. ${ }^{14}$ From these three case studies, the article identifies two key requirements for realizing the instruments' social control potential. First, there is a need for favourable legal and political climates that permit and legitimize implementation; and this depends on the nature of religion-state relations in a particular jurisdiction. Second, the religious bodies producing these instruments must put what they preach into practice. Following up on the production of these instruments by translating its contents into practical action is vital for social enforcement since state sanctions are inaccessible.

The article's focus on the second form of implementation aims to contribute to existing discussions on how religion can meaningfully contribute to environmental protection alongside national environmental laws and regulations; thereby supplementing, not substituting, national efforts directed to that end. ${ }^{15}$ It also challenges

10. On the other hand, anthropological literature on Indonesian environmentalism fills this gap: Gade (n 8).

11. Contemporary literature on the subject most propose, not document, the implementation of Islamic environmental norms. See eg, Ali Ahmad, 'Islamic Water Law as an Antidote for Maintaining Water Quality' (1999) 2 University of Denver Law Review 169; Walied El-Malik, 'State Ownership of Minerals under Islamic Law' (1996) 14 Journal of Energy and Natural Resources Law 310; Dina M Abdelzaher, Amr Kotb and Akrum Helfaya, 'Eco-Islam: Beyond the Principles of Why and What, and Into the Principles of How' (2019) 1533 Journal of Business Ethics 623. For works that do document Islamic norm application, see eg Kaveh L Afrasiabi, 'The Environmental Movement in Iran: Perspectives from Below and Above' (2003) 57 Middle East Journal 432; Umar F Moghul and Samir HK Safar-Aly, 'Green Sukuk: The Introduction of Islam's Environmental Ethics to Contemporary Islamic Finance' (2014) 27 Georgetown International Environmental Law Review 1.

12. See Robert W Hefner, Shari a Politics: Islamic Law and Society in the Modern World (Indiana University Press, 2011).

13. About 61 percent of Muslims live in the Asia-Pacific region: 'The Changing Global Religious Landscape' (n 2).

14. Although the proper plural form of fatwa in Arabic is fatāwa, 'fatwas' in the English plural form is used here instead. The same goes for other non-English nouns, eg, khutbah and pesantren. One spelling for 'Shari'a' is used consistently.

15. See Nadia B Ahmad, 'Faith-Based Approaches to Ecological Harmony and Environmental Protection' (2020) 21 Rutgers Race and Law Review 1. 
the modern perception that environmental law is an exclusively secular matter in which religion is irrelevant. ${ }^{16}$

The article proceeds as follows: Section 2 explores the two forms in which Islamic environmental law is implemented today. With regard to the second form (i.e., nonbinding religio-legal instruments), the production and utility of fatwas and khutbahs are elucidated. The article's three case studies are covered in Section 3, 4 and 5 respectively. Thereafter, based on the case studies, Section 6 fleshes out the two key requirements to proper implementation of Islamic environmental law through non-binding instruments. Section 7 concludes.

\section{IMPLEMENTING ISLAMIC ENVIRONMENTAL LAW}

This section examines in turn the two approaches to implementing Islamic environmental law today, i.e., implementation through constitutions and implementation through non-binding religio-legal instruments. With regard to the latter, which is the focus of the article, two instruments are featured i.e., fatwas and khutbahs, and their production and utility are expounded.

\subsection{Islamic environmental norms through constitutions}

Historically, Islamic environmental law regulated the use of public resources such as water bodies or designate wildlife reserves for animals through the use of zoning (harim). ${ }^{17}$ In his 1964 study, Caponera documented how the use of zoning by that time has largely devolved from the realm of state law to that of customary law, practiced only by communities in rural areas. ${ }^{18}$ Today, the limited scope of Islamic law in modern legal systems determines how and the extent to which Islamic environmental law can be implemented. Few Muslim-majority countries implement Islamic public (criminal) law; others exclusively codify Islamic personal status laws on marriage, divorce, succession and probate. ${ }^{19}$ Since environmental protection is of public importance and not private interest, the implementation of Islamic environmental law at through state law is predictably limited as well.

This limit is overcome in a handful of Muslim-majority countries where the Islamic religion is given constitutional status. In some, Islam is entrenched as the state religion. In others, it is a source of legislation and policy principles. For many, the religion is an integral aspect of national and cultural identity. ${ }^{20}$ The variations of how Islam is weaved into the constitutional fabric of these modern states make some 'Islamic

16. Anthony Gillepie, International Environmental Law, Policy and Ethics (Oxford University Press, 1997) 80-81.

17. Ahmad, 'Islamic Water Law as an Antidote for Maintaining Water Quality' (n 11) 184.

18. Caponera (n 9) 69.

19. See Ira M Lapidus, 'State and Religion in Islamic Society' (1996) 151 Past \& Present 3, 26-27; Rudolph Peters, 'From Jurists' Law to Statute, What Happens When the Shari 'a is Codified' (2002) 7 Mediterranean Politics 82.

20. See generally Hefner (n 12); Rüdiger Wolfrum, 'Constitutionalism in Islamic Countries: A Survey from the Perspective of International Law' in Rainer Grote and Tilmann Röder (eds), Constitutionalism in Islamic Countries: Between Upheaval and Continuity (Oxford University Press, 2012) 77-88. 
states' as such and others not. ${ }^{21}$ Regardless, these constitutional arrangements support the application of Islamic environmental law through constitutional provisions. It is trite that all laws are conferred authority and power by constitutions. Thus, a necessary character of these legislations is constitutionality, i.e., the legislations in totality (i.e., from its purpose to its operation) are not and cannot be contrary to the letter and spirit of the constitution. This logic similarly applies to these 'Islamic' constitutions, hence permitting the claim that legislations borne of those constitutions are and must be Shari'a-compliant. It follows then that the constitutional recognition of Islam in these countries open the doors to the presumption that Islamic environmental law is part of their national legal systems.

Examples of where the presumption of compliance applies may be found in jurisdictions where Islam's role in the promulgation of law is explicitly provided for in their constitutions. In Saudi Arabia, its constitutional document - the Basic Law of Government 1992 (Basic Law) - proclaims Islam to be the state religion, and the Shari'a and the Prophetic Sunna ${ }^{22}$ as its constitution. ${ }^{23}$ More importantly, Articles 7 and 8 of the Basic Law explicitly states that 'Governance in the Kingdom of Saudi Arabia derives its authority from the Book of God Most High and the Sunna of his Messenger, both of which govern this Law and all the laws of the State' 24 and 'shall be based on justice, shura (consultation), and equality in accordance with the Islamic Shari 'a' ${ }^{25}$ Thus, all Saudi laws are grounded on or made to comply with Islamic law; and accordingly, the state obligation to "endeavour to preserve, protect and improve the environment and prevent its pollution' under Article 32 of the Basic Law and its Environmental Act $2001^{26}$ espouses Islamic norms.

Similarly, the Iranian Constitution proclaims Islam to be its state religion, ${ }^{27}$ political ideology, ${ }^{28}$ and source of principles for national governance. ${ }^{29}$ Additionally, '[a]ll civic, penal, financial, economic, administrative, cultural, military, political, and other laws and regulations must be based on an Islamic criteria' ${ }^{30}$ Thus, Article 50 of Iranian Constitution creating a public obligation for environmental protection and forbids 'all activities, economic or otherwise, which may cause irreversible

21. Wolfrum, ibid, 78-79. For Wolfrum, 'Islamic states' are states that constitutionally 'adopted Islam as the ideological foundation for its political institutions'; while states such as Turkey and Azerbaijan, despite being Muslim-majority states, are 'secular states' because their constitutions do not.

22. The Sunna are the sayings, decisions, and actions of the Prophet Muhammad in response to issues and problems faced by the people around him. These are collectively referred to as the 'way' or 'sunnah' of the Prophet and are derived from narrations relayed by his closest companions, or hadith.

23. Saudi Basic Law of Government 1992, art 1. For an in-depth study of Saudi environmental law and how Islamic environmental law manifests in it, see Norah binti Hamad, 'Foundations for Sustainable Development: Harmonizing Islam, Nature and Law' (SJD dissertation, Pace University 2017) <https://digitalcommons.pace.edu/lawdissertations/20/> accessed 29 July 2019.

24. Saudi Basic Law of Governance 1992, art 7.

25. Ibid, art 8 .

26. Officially referred to as Royal Decree No. M/34 of 22 Rajab 1422 on the General Regulation of the Environment.

27. Iranian Constitution, art 12.

28. Ibid, Preamble.

29. Ibid, art 2 .

30. Ibid, art 4 . 
damage to the environment'; ${ }^{31}$ as well as the 1974 Environmental Protection and Enhancement Act and all other sectoral environmental statutes, ${ }^{32}$ may be regarded as constitutionally grounded and legitimized by Islamic principles. ${ }^{33}$

In the case of Morocco, the country constitutionally identifies itself as a 'sovereign Muslim State' ${ }^{34}$ with Islam as the state religion. ${ }^{35}$ The Moroccan King is also proclaimed as the Defender of the Islamic Faith (Amir Al Mouminine), presiding over the development and promulgation of Islamic laws. ${ }^{36}$ More importantly, the laws enacted in Morocco are vetted by the Royal Religious Council (le Conseil supérieur de Ouléma) to ensure their 'Islamic identity'. ${ }^{37}$ Therefore, the right to a healthy environment under Article 31 of the constitution and environmental laws such as the 2003 Environmental Protection and Enhancement $\mathrm{Law}^{38}$ can all be regarded to comply with the Shari 'a. ${ }^{39}$

In Egypt, Article 2 of its constitution entrenches Islam as the state religion and recognizes 'the principles of Islamic Shari 'a as the main source of legislation' ${ }^{40}$ Consequently, the Egyptian Environmental Law $1994^{41}$ and other environmental statutes ${ }^{42}$ are founded on principles of the Shari'a. In Pakistan, Islam is constitutionally enshrined as the state religion. ${ }^{43}$ All Pakistani laws must 'be brought in conformity with the

31. Ibid, art 50.

32. These include, the 1995 Air Pollution Act, 2004 Waste Management Act, 1967 Game and Fish Law, 1967 Plant Protection Act, and to a limited extent, the 2004 Fourth Development Plan Act.

33. cf Afrasiabi (n 11) 437-38. Afrasiabi points that the heavy lifting in enforcing Islamic environmental norms in Iran is done by environmental NGOs as opposed to the Iranian state despite the clergy also occupying positions in environmental agencies.

34. Dahir No. 1-11-91 du 27 chaabane 1432 (29 juillet 2011) portant promulgation du texte de la constitution [Royal Decree No. 1-11-91 of 27 Sha'aban 1432 (29 July 2011) Promulgating the Text of the Constitution] [in French], Preamble.

35. Ibid, art 3.

36. Ibid, art 41.

37. Mohamed Madani, Driss Maghraoui and Saloua Zerhouni, 'The 2011 Moroccan Constitution: A Critical Analysis' (International Institute for Democracy and Electoral Assistance, 2012) 20 $<$ www.idea.int/sites/default/files/publications/the-2011-moroccan-constitution-critical-analysis. pdf $>$ accessed 8 July 2020.

38. Dahir No. 1-03-59 portant promulgation de la loi No. 11-03 relative à la protection et à la mise en valeur de l'environnement [Royal Decree No. 1-03-59 Promulgating Law No. 11-03 concerning the Protection and Enhancement of the Environment] [in French].

39. For example, Dahir No. 1-03-60 du 10 rabii I 1424 (12 mai 2003) portant promulgation de la loi No. 12-03 relative aux études d'impact sur l'environnement [Royal Decree No. 1-03-60 of 10 Rabi' al-Awwal 1424 (12 May 2003) Promulgating Law No. 12-03 concerning Environmental Impact Studies] [in French]; Dahir No. 1-03-61 portant promulgation de la loi No. 13-03 relative à la lutte contre la pollution de l'air [Royal Decree No. 1-03-61 Promulgating Law No. 13-03 on Combatting Air Pollution] [in French].

40. Egyptian Constitution, art 2. See also Tamir Moustafa, 'The Islamist Trend in Egyptian Law' (2010) 3 Politics \& Religion 610; Clark B Lombardi, State Law as Islamic Law in Modern Egypt: The Incorporation of the Sharī'a (Brill, 2006) 123-140; Clark B Lombardi, 'Constitutional Provisions Making Sharia "A" or "The" Chief Source of Legislation: Where Did They Come from? What Do They Mean? Do They Matter?' (2013) 28 American University International Law Review 733.

41. Law No. 4 of 1994 Promulgating the Environmental Law and its Executive Regulation, as amended by Law No. 9 of 2009 and Law (Presidential Decree) No. 105 of 2015 (Egypt).

42. For example, Law 102 of 1983 on the Protection of Nature; Law 48 of 1982 on the Protection of the Nile and Waterways from Pollution (Egypt).

43. Constitution of Pakistan, art 2. 
Injunctions of Islam as laid down in the Holy Qur'an and Sunnah' under Article 227 of the Constitution of Pakistan, and that 'no law shall be enacted repugnant to such Injunctions' ${ }^{44}$ Additionally, an 'Islamic Council' is constitutionally established to ensure conformity. ${ }^{45}$ Therefore, Pakistan's environmental legislation such as the Pakistan Environmental Protection Act $1997^{46}$ conform to the 'Injunctions of Islam'.

Unlike in Saudi Arabia, Iran, and Morocco, however, laws' compliance with Islamic principles mandated by the Egyptian and Pakistani constitutions have been brought before the courts for enforcement.

In Egypt, where Islamist litigation against allegedly 'un-Islamic' laws on the basis of Article 2 is common, ${ }^{47}$ the constitutionality of an environmental agency's administrative decision has been challenged due to its violation of Article $2 .{ }^{48}$ In that case, several firms constructed and operated cement and diamond factories adjacent to a residential area, emitting harmful air pollutants into the air and thus adversely affected the health of residents there. It was discovered that the agency did not conduct an environmental impact assessment (EIA) prior to the construction and operation of these factories. The lawyers argued that the agency's non-conducting of an EIA in this context violated Article 2, specifically, the 'enjoining good and preventing evil' ('amr ma'rüf wa nahi munkar) principle in Islamic law, because their administrative decision failed to protect 'the health of citizens when it continued to allow a local cement factory to emit harmful air pollutants'. ${ }^{49}$

The Supreme Court of Pakistan, to a similar effect, has held that Pakistan's constitutional framework makes compatible Islamic principles of justice, equality, and democracy with secular fundamental rights. ${ }^{50}$ Consequently, Islamic principles are manifested within in as well as motivate the public interest litigation (PIL) mechanism in Article 184A of the constitution. ${ }^{51}$ Hence, while no environmental PIL cases thus far have been argued on the basis of an Islamic environmental right per se, the range of Pakistani PIL cases involving environmental rights such as Shehla Zia v WAPDA ${ }^{52}$ and Human Rights Case (Environmental Pollution in Baluchistan) ${ }^{53}$ all manifest the Islamic right to access to justice, among others. ${ }^{54}$

44. Ibid, art 227(1).

45. Ibid, arts 229 and 230.

46. Pakistan Environmental Protection Act (Act No. XXXIV of 1997).

47. Clark B Lombardi and Connie J Cannon, 'Transformations in Muslim Views about "Forbidding Wrong": The Rise and Fall of Islamist Litigation in Egypt' in Robert W Hefner (ed), Shari'a Law and Modern Muslim Ethics (Indiana University Press, 2016) 135, 145-49.

48. Ibid, 151.

49. Helmi al-Namnam, Al-Hisba wa Hurriyat al-Ta'bìr [The Hisba and Freedom of Expression] [in Arabic] (Al-Shabaka Al-'Arabiyya al-Ma'lūmāt Huqūq al-Insān, 2012) 186-190.

50. Benazir Bhutto v The Federation of Pakistan PLD 1988 SC 416. See Muhammad Afzal Zullah, 'Human Rights in Pakistan' (1992) 18 Commonwealth Law Bulletin 1343, 1346.

51. Chaudhry Akbar Ali v Secretary, Minister of Defence, Rawalpindi (1991) SCMR 2114 (Supreme Court of Pakistan) at 2116. For a brief summary of PIL in South Asia, see Ridwanul Hoque, Judicial Activism in Bangladesh: A Golden Mean Approach (Cambridge Scholars Publishing, 2011) 90-91.

52. PLD 1994 SC 416.

53. PLD 1994 SC 102.

54. Martin Lau, 'Islam and Judicial Activism: Public Interest Litigation and Environmental Protection in the Islamic Republic of Pakistan' in Alan E Boyle and Michael R Anderson (eds), Human Rights Approaches to Environmental Protection (Clarendon Press, 1996) 296-301. 


\subsection{Implementation by non-binding instruments}

Nevertheless, not all states with a significant Muslim population have constitutions that entrench the Islamic religion. Indeed, the main benefit of the first form as elucidated above is the availability of enforcement mechanisms under constitutional law; as shown in the cases of Egypt and Pakistan, decisions of parliamentarians and bureaucrats can be scrutinized on substantive religious grounds. Unfortunately, this is impossible for Muslims that do not live in those countries. An alternative approach to implementation can be pursued outside the realm of state governance in private governance: the use of non-binding instruments. Two of these instruments are featured in this section: the fatwa and the khutbah. In general, these instruments may be produced by any 'religious authority' in a Muslim community - from Islamic organizations (e.g., Egypt's Al Azhar) to independent or mosque-based Islamic scholars who is qualified to produce them.

The first of these instruments is the fatwa. Fatwas are non-binding religious rulings that only serve as scholarly opinions or advice. ${ }^{55}$ Moreover, they can only be made by a 'mufti' :56 an Islamic jurist 'driven above all by a profound religious commitment which demanded of them, among other things, the articulation of a law that would deal with all the problems of society'. ${ }^{57}$ Muftis are historically and theoretically part of the 'non-state', serving as the state's 'pious opposition' and were mostly independent of political influence. ${ }^{58}$ Thus, in his capacity as a scholar, the mufti 'controlled the law on the level of discourse'. ${ }^{59}$ While fatwas are not law per se, a fatwa can become 'law' when it is endorsed by judges in court in their judgments. ${ }^{60}$ Indeed, some muftis in the past served as judges or expert witnesses to facilitate such an endorsement, or are co-opted by the state entirely to advance their political interests. ${ }^{61}$

In form, a fatwa is similar to a modern legal opinion. It involves a question containing pertinent legal issues, and the mufti's answer addressing those issues from the position of Islamic jurisprudence. The proponent of the legal questions may be private individuals, courts, or even the state. ${ }^{62}$ The question may also be abstract, hypothetical, or fact-laden, but the mufti's rulings are limited to the legal issues and facts provided. Regardless, the mufti is expected to 'present the law of Islam [in] an objective form' ${ }^{\prime} 3$ that clearly states the position of the Shari'a on any given issue. Hence, fatwas are created to guide Muslims in their day-to-day lives. In the case of Muslim-majority states where fatwas influence secular government policies, they

55. Farhanin A Asuhaimi et al, 'The Role and Position of Fatwa in Malaysian Court' (2017) 25 Pertanika Journal of Social Science and the Humanities 227.

56. Frank E Vogel, Islamic Law and Legal System: Studies of Saudi Arabia (Brill, 2000) 5. 57. Wael B Hallaq, The Origins and Evolution of Islamic Law (Cambridge University Press, 2005) 63.

58. Knut S Vikør, Between God and the Sultan: A History of Islamic Law (Oxford University Press, 2005) 143; Roy P Mottahedeh and Baqir as-Sadir, Lessons in Islamic Jurisprudence (Oneworld, 2005) 7.

59. Haim Gerber, Islamic Law and Culture, 1600-1840 (Brill, 1999) 56.

60. Sherman A Jackson, Islamic Law and the State: The Constitutional Jurisprudence of Shihāb al-Dīn al-Qarāfi (Brill, 1996) 145-46.

61. Vikør (n 58) 145-46.

62. Ibid, 141-43.

63. Ibid, 149-50. 
indirectly apply to non-Muslims as well. ${ }^{64}$ Consider the following fatwa by Dar alIfta, in Figure 1, an internationally renowned fatwa-issuing body in Egypt, issued in response to a request for an environmental fatwa. ${ }^{65}$

\section{Miscellaneous}

\begin{tabular}{|c|c|c|c|}
\hline Like 0 & Share & Number : 825789 & Date : $10 / 31 / 2018$ \\
\hline
\end{tabular}

Assalamu'alaykum. I have several questions: 1) What are the duties and obligations of Muslims to the environment? 2) What is the Islamic position on the limits of a Muslim's compliance with their country's laws? Thank you and Jazakallah khayran.

Answer : Fatwa Council

1. Muslims' duty towards the environment stems from their understanding that man is a vicegerent on earth and God commanded them to work for development and not destruction. 2-Muslims are commanded in Shari'ah to respect the laws of the countries they live in as per the words of God Almighty, "O you who have believed, obey Allah and obey the Messenger and those in authority among you." (Surah An-Nisa: 59). This is provided these laws do not contradict the fundamentals of religion. God Almighty knows best.

Figure 1 A fatwa issued by Dar al-Ifta to a request for an environmental fatwa

Here, two questions were submitted: one concerning the Islamic legal position on a Muslim's environmental obligations, and the other on the limits of a Muslim's compliance with national (environmental) law. The answer to the first question immediately raised the Shari'a's stewardship principle to establish an obligation. The second question was subsequently answered by first stating the general rule on obedience to the state, with a Quranic verse as legal authority. The general rule is thereafter qualified by a condition precedent: that these state laws must not 'contradict the fundamentals of [the Islamic] religion'. Most if not all fatwas use this format - providing answers to legal questions in a systematic manner.

The second instrument is the khutbah. Traditionally, the khutbah is produced and delivered by the imam (prayer leader) in his role as the khatib (sermon-giver) before congregational prayers such as the weekly Friday prayers and festive Eid prayers. ${ }^{66}$ A khutbah may be prepared beforehand or delivered impromptu. At their core, khutbahs are 'judgments': religious leaders state and/or reiterate the position of the religion on particular issues and instruct the faithful on compliance. MB Hooker adeptly describes khutbahs as "public transmission" of Islamic law which function ... is purely didactic: to instruct the faithful in religion ... instructing the Muslim in his or her individual duty to God as this is understood in a particular place, at a

64. Indirect application to non-Muslims may be the case in the country examples in Section 2.1 . See Section 5.1 below for how this pans out in Indonesia. In Malaysia, state Islamic law enactments are explicit on the exclusive applicability of fatwas to Muslims within the state: see Section 4.2 for the case of Perlis State.

65. Fatwa Council of Dar al-Ifta', Fatwa No. 825789 (Dar al-Ifta' al-Missriyyah, 31 October 2018) <http://dar-alifta.org/Foreign/f.aspx?ID=825789> accessed 14 March 2019. This fatwa request was submitted by the author in October 2018.

66. 'Khutbah' in John L Esposito (ed), The Oxford Dictionary of Islam (Oxford University Press, 2003) <www.oxfordreference.com/view/10.1093/acref/9780195125580.001.0001/acref9780195125580-e-1304?rskey=hugb5D\&result=1304> accessed 28 July 2020. 
certain time'. ${ }^{67}$ Khutbahs are also a means for 'religious and moral criticism of the governments in power' in countries where there is 'an absence of freedom of expression' ${ }^{68}$

Content-wise, khutbahs must be 'interesting and [contain] practically oriented lesson[s] on Islamic morality and values', made palatable for the masses. ${ }^{69}$ Group pronouns such as 'we' and 'our' must also be used in khutbahs to support the 'internalization of communal norms and the expression of the feelings of communality and unity'. ${ }^{70}$ From a social control perspective, this inculcates 'shared sentiments and the feelings of unity by the faithful during the [congregational] prayer: it is a renewal of the worshippers' commitment to their shared sets of moral and religious values' ${ }^{71}$ Therefore, by being 'an important source of the community's morality and moral judgements', pronouncing on the 'rules' of the community and the consequences of rule violation in this world and the hereafter, ${ }^{72}$ the mosque functions as an agent of social control through khutbahs.

The production of these religio-legal instruments has not changed much over the past 1441 years at the fundamental level - they are still produced by religious authorities within a particular community. However, what counts as a 'religious authority' has changed to fit the context of modern nation-states. In the Article's case studies that follow, fatwa and khutbah production, and thereafter, their use in implementing Islamic environmental law, are found on political and legal infrastructures that authorize and legitimize their existence and application.

\section{KHUTBAH-CENTRIC IMPLEMENTATION: THE CASE OF SINGAPORE}

\subsection{Fatwa and Khutbah in Singapore law}

Singaporean Muslims make up about 14 percent of the population. ${ }^{73}$ Although no religion is given constitutional status due to the diverse nature of its society, ${ }^{74}$ Article 153 of the Singapore Constitution obligates Parliament to 'make provision for regulating Muslim religious affairs' ${ }^{75}$ This resulted in the enactment of the Administration of Muslim Law Act (AMLA) ${ }^{76}$ in 1968, replacing colonial ordinances on

67. MB Hooker, Indonesian Syariah: Defining a National School of Islamic Law (ISEAS, 2008) 129.

68. 'Khutbah' (n 66).

69. Ali Wardak, 'The Mosque and Social Control in Edinburgh's Muslim Community' (2002)

3 Culture \& Religion 201, 214.

70. Hooker (n 67) 217.

71. Wardak (n 69) 217.

72. Ibid, 214-15.

73. Department of Statistics, 'General Household Survey 2015' (Department of Statistics, Ministry of Trade \& Industry, Republic of Singapore 2016) 25 <www.singstat.gov.sg/-/ media/files/publications/ghs/ghs2015/ghs2015.pdf> accessed 12 June 2020.

74. See Kevin YL Tan, The Constitution of Singapore: A Contextual Analysis (Hart, 2015) 233-37.

75. Constitution of the Republic of Singapore, art 153. This is because the Malays - a minority ethnic group recognized as the island's natives under art 152 of the Constitution - form 99.2 percent of Muslims: 'General Household Survey 2015' (n 73).

76. Administration of Muslim Law Act (Cap 3, Rev Ed 2009). 
Islamic law. ${ }^{77}$ This statute is the legal basis for the management of Islamic affairs in Singapore, ${ }^{78}$ including fatwa and khutbah production. Apart from administrative matters, such as mosque management and the collection of mandatory alms or zakat, AMLA governs Muslim personal laws concerning matrimony, divorce, and inheritance. $^{79}$

The power of fatwa and khutbah production in Singapore is vested in the Islamic Religious Council of Singapore (MUIS), ${ }^{80}$ a statutory board created by AMLA to, among others, 'administer matters relating to the Muslim religion and Muslims in Singapore'. ${ }^{81}$ Under s 31 of AMLA, fatwa production is a function of MUIS' Legal Committee ${ }^{82}$ chaired by the Mufti of Singapore. ${ }^{83}$ The Committee issues fatwas in response to requests submitted by members of the public ${ }^{84}$ and/or at its own discretion. ${ }^{85}$ They may choose to not answer requests deemed 'frivolous or for other good reason ought not to be answered'; 86 and a fatwa may only be issued if Committee members vote unanimously in favour of its contents. ${ }^{87} \mathrm{~A}$ court may also request for an opinion from the Committee when 'any question of the Muslim law falls for decision', ${ }^{88}$ but these opinions are non-binding and persuasive at best. ${ }^{89}$ AMLA does not explicitly provide for the production of khutbah; it is, however, a function performed by MUIS' Office of the Mufti ${ }^{90}$ as part of the organization's role in issuing 'religious guidance to the community'. ${ }^{91}$

\subsection{A preference for Khutbahs in Singapore?}

Generally, the approach to implementing Islamic environmental law in Singapore is khutbah-centric, evidenced by the absence of fatwas concerning the environment. The reasons for this are unknown, although legally-speaking, this means that a fatwa request has not been submitted, initiated and/or considered by the Fatwa Committee under Article 32 of AMLA. The first scenario, i.e. a request from a member of the public, is impossible considering the author's personal request for a climate

77. Ahmad Nizam Abbas, 'The Islamic Legal System in Singapore (2012) 21 Pacific Rim Law \& Policy Journal 163, 164-65.

78. Singapore Parliamentary Debates, Official Report (17 August 1966) vol 25 at col 245 (Inche Mohd Ariff Bin Suradi, MP for Kampong Kembangan).

79. Abbas (n 77) 166-67.

80. MUIS is the acronym for its name in Malay: 'Majlis Ugama Islam Singapura'.

81. AMLA, s 3 .

82. Ibid, s 31 .

83. Ibid, s 31(4).

84. Ibid, s 32(1).

85. Ibid, s 32(6).

86. Ibid, s 32(3).

87. Ibid, s 32(4).

88. Ibid, s 32(7).

89. Shafeeg bin Salim Talib and Anor v Fatimah bte Abud bin Talib [2010] SGCA 11; [2010] 2 SLR 1123 at [64]-[65] ('Shafeeg Case').

90. Office of the Mufti, 'Khutbah' (MUIS) <www.muis.gov.sg/officeofthemufti/Khutbah> accessed 5 August 2020.

91. Majlis Ugama Islam Singapura, 'About MUIS - Roles \& Functions' (MUIS) <www.muis. gov.sg/About-MUIS/Roles-Functions> accessed 5 August 2020. 
change fatwa from the Committee in July $2019 .{ }^{92}$ This request was responded to by a call from a MUIS officer in August 2019 to inform, among others, of an environmental khutbah being released for the Friday congregational prayers on that week, and that the fatwa request will be given to the Mufti for consideration. ${ }^{93}$ It is noteworthy, that, in his query concerning whether the author intends to continue pursuing the fatwa request, the officer hinted at the sufficiency of environmental khutbahs to fulfil the objectives of the request. ${ }^{94}$ Based on the fact that MUIS has not issued an environmental fatwa, and the author's interactions with them on his personal fatwa request, it is possible that MUIS prefers khutbahs over fatwas in this context.

Regardless of preferences, the Office of the Mufti has published 14 environmental khutbahs between 2016 and 2020. These khutbahs either address environmental issues directly or have the environment as the general theme, and 13 of them are produced for Friday prayers while one in 2018 for Eid al-Fitr prayers. They are available in English, Malay and Tamil languages.

Table 1 MUIS environmental khutbahs, 2016-2020

\section{No. Date (Gregorian/Islamic)}

1. 1 January 2016 / 20 Rabiulawwal 1437

2. 11 March 2016 / 2 Jamadilakhir 1437

3. 27 May 2016 / 20 Sya aban 1437

4. 24 March 2017 / 25 Jamadilakhir 1438

5. 6 October 2017 / 15 Muharram 1439

6. 10 November 2017 / 21 Safar 1439

7. 8 June 2018 / 23 Ramadan 1439

8. 15 June 2018 / 1 Syawal 1439

9. 8 March 2019 / 1 Rejab 1440

10. 15 March 2019 / 8 Rejab 1440

11. 12 July 2019 / 9 Zulkaedah 1440

12. 23 August 2019 / 22 Zulhijjah 1440

13. 11 October 2019 / 12 Safar 1441

14. 20 March 2020 / 25 Rejab 1441
Title

Noble Values from the Life of Rasulullah s.a.w. Doing Justice Towards Allah's Blessings

Spreading the Message of Mercy

Balance in God's Creations

Make Every Step and Breath an Act of Worship to Allah s.w.t.

Holding on to the value of Justice (The story of Umar r.a.)

Strengthening Our Relationship with Allah s.w.t. through Istiqamah (Consistency in Action)

Khutbah Aidilfitri - The Meaning and Potential of Spirituality

Living Prosperously Through Environmental Conservation

Attaining Allah's Acceptance Through Mercy and Compassion for All Creations

Striking the Balance

Our Role in Protecting the Environment

Ethics and Compassion in Relationships

A Mazmumah (Accursed) Trait: Wastefulness

An interesting observation from these khutbahs is how MUIS has used them as a means of informing and advising Muslims of the state's environmental policies. Notably, the

92. See the author's Twitter status posted on 24 July $2019,<$ https://twitter.com/shazology/ status/1153880618939215872?s=20> accessed 5 August 2020.

93. See the author's Twitter status posted on 22 August 2019, <https://twitter.com/shazology/ status/1164340348757274625?s=20> accessed 5 August 2020.

94. In the author's request, it was argued that 'such a fatwa would, inter alia, outline the general duties of Muslims to the environment, how Muslims should respond to climate change, the role of the community as an exemplary community in Singapore in supporting the government's efforts to combat climate change, etc.'. 
Singapore government's commitment to climate action since 2018 has been mirrored by a surge in environmental khutbahs in between 2018 and 2019. More interesting is how two of these khutbahs, i.e. 'Doing Justice towards Allah's Blessings'95 and 'Balance in God's Creation', ${ }^{96}$ may be seen as responding to a related issue - water resources and government plans to increase water prices. ${ }^{97}$ Both khutbahs contain advice on responsible water usage in Islam, and its application in Singapore's context. Therefore, it could be said that khutbahs play an important role in implementing Islamic environmental law - both independently or in response to current affairs; and in Singapore, they may be the preferred way to do so.

\section{IMPLEMENTATION BY FATWA AND KHUTBAH: THE CASE OF MALAYSIA}

\subsection{Fatwa and Khutbah in Malaysian law}

In Malaysia, Muslims form about 60 percent of the population. As one of the 'traditional elements' of the Federal Constitution of Malaysia (FC) ${ }^{98}$ Islam is enshrined as 'the religion of the Federation'. ${ }^{99}$ Nevertheless, the FC is 'the supreme law of the Federation', ${ }^{100}$ and its provisions on religion cannot 'derogates (sic) from any other provision of this Constitution'. ${ }^{101}$ As a federal elective constitutional monarchy with parliamentary democracy, the highest religious authority in Malaysia are its nine hereditary Malay kings, who are Heads of the Islamic Religion of their respective states, and the Yang Di-Pertuan Agong - Malaysia's high king - as the federal Head. ${ }^{102}$ In 1968, in the exercise of his constitutional powers and in consultation with the Conference of

95. Office of the Mufti, 'Doing Justice Towards Allah's Blessings' (MUIS, 11 March 2016) $<$ www.muis.gov.sg/-/media/Files/OOM/Khutbah/English/PDF/2016/E16Mar11-Doing-JusticeTowards-Allahs-Blessings.pdf $>$ accessed 22 July 2020.

96. Office of the Mufti, 'Balance in God's Creations' (MUIS, 24 March 2017) <www.muis. gov.sg/-/media/Files/OOM/Khutbah/English/PDF/2017/E17Mar24-Balance-in-God-Creations. pdf> accessed 22 July 2020.

97. Public Utilities Board, 'Water Prices' <www.pub.gov.sg/watersupply/waterprice> accessed 25 February 2019. See also Chew Hui Min, 'Singapore Budget 2017: Water prices to increase by 30\% from July 1 in two phases' The Straits Times (Singapore, 20 February 2017) <www. straitstimes.com/singapore/singapore-budget-2017-water-prices-to-increase-by-30-from-july-1-intwo-phases> accessed 25 February 2019; Monica Kotwani, 'Budget 2017: Water prices to rise by $30 \%$ over 2 years' (Channel News Asia, 20 February 2017) <www.channelnewsasia.com/news/ singapore/budget-2017-water-prices-to-rise-by-30-over-2-years-7595390> accessed 25 February 2019.

98. Tun Haji Mohd Salleh bin Abas, 'Traditional Elements of the Malaysian Constitution' in FA Trindade and HP Lee (eds), The Constitution of Malaysia: Essays in Honour of Tun Mohamed Suffian (Oxford University Press, 1986) 5-8.

99. FC, art 3(1). The other three traditional elements are: the preservation of the traditional Malay rulers in the postcolonial Malayan state, the privileging of Malays, and the installing the Malay language as the national and official language: Abas (n 98) 1.

100. Ibid, art 4.

101. Ibid, art 3(4).

102. Ibid, arts 3(2), 3(3) and 3(5). There are thirteen states in Malaysia, nine are ruled by hereditary Malay kings, three are governed by Chief Ministers, and one (Federal Territories) by the Yang Di-Pertuan Agong (High King of Malaysia). The nine Malay kings take turns to be the High King. 
Rulers (Majlis Raja-Raja), ${ }^{103}$ the then-Yang Di-Pertuan Agong established the National Council of Islamic Affairs (MKI) ${ }^{104}$ to advise and submit recommendations on matters pertaining to the administration of the Islamic religion to the Conference, Federal Government, and State Governments; as well as promote uniformity of Islamic laws throughout the country. The MKI consists of the muftis of all thirteen Malaysian states and five experts appointed by the Yang Di-Pertuan Agong. ${ }^{105}$

It follows that fatwa-production happens at the federal and state level. At the federal level, the power of fatwa-production is vested in the National Fatwa Committee (NFC) of the MKI. The NFC comprises of the 13 state muftis, five theologians, and two officials from the judicial/legal service or legal profession appointed by the Prime Minister. ${ }^{106}$ It primarily 'considers, decides, and issues fatwas' at the request and approval of the Conference. ${ }^{107}$ However, NFC fatwas are non-binding at the state level because the power of fatwa-production there lies with their respective Islamic religious departments. ${ }^{108}$ Individual state legislation on the administration of Islamic law empowers these departments to issue fatwas when the Head of State (the state's king or Chief Minister) instructs the issuing of a fatwa and when requested by a member of the public. In most states, the State Fatwa Committee chaired by the State Mufti is empowered to issue fatwas. ${ }^{109}$ In the Federal Territories, ${ }^{110}$ the State Mufti is empowered to issue fatwas of his own design, but is required to consult his Fatwa Committee. ${ }^{11}$ The only states where a State Mufti can issue fatwas independently are Kedah and Pahang. ${ }^{112}$ Notably, state-level fatwas apply exclusively to Muslims living in that state and never to non-Muslims; and they can be made binding if

103. Jabatan Kemajuan Islam Malaysia, 'Jakim Berperlembagaan' (JAKIM, 4 August 2020) $<$ www.islam.gov.my/mengenai-jakim/jakim-berperlembagaan> accessed 5 August 2020.

104. MKI is the acronym for its name in Malay: 'Majlis Kebangsaan Bagi Hal Ehwal Ugama Islam'.

105. G25, 'Administration of Matters Pertaining to Islam', $125<\mathrm{https}: / / 0884 \mathrm{c} 48 \mathrm{f}-293 \mathrm{a}-4 \mathrm{fef}-$ 9992-314485a1e02f.filesusr.com/ugd/471d06_862b4cefa16c4cbe8c4303a04367cf77.pdf> accessed 5 August 2020. On Malaysia's unique elective monarchy, see generally Dian AH Shah, 'Democracy and the Monarchy in Malaysia' (I-CONnect Blog, 6 February 2019) <www.icon nectblog.com/2019/02/democracy-and-the-monarchy-in-malaysia/> accessed 5 August 2020.

106. Ibid, 127.

107. Jabatan Kemajuan Islam Malaysia, 'Jawatankuasa Fatwa Majlis Kebangsaan Bagi Hal Ehwal Ugama Islam Malaysia' (JAKIM) <http://e-smaf.islam.gov.my/e-smaf/fatwa/latar_bela kang/penubuhan> accessed 5 August 2020; Zaini Nasohah, 'Undang-undang Penguatkuasaan Fatwa di Malaysia' (2005) 27 Islāmiyyāt 25, 31-32.

108. Asuhaimi et al (n 55) 229.

109. Johor (Administration of the Islamic Religion (Johor) Enactment 2003, ss 46-47), Kelantan (Council for the Islamic Religion and Malay Custom Enactment 1994, s 36), Melaka (Administration of the Islamic Religion (Melaka) Enactment 2002, ss 34-36), Negeri Sembilan (Administration of the Islamic Religion (Negeri Sembilan) 2003, ss 48-49), Perak (Administration of the Islamic Religion Enactment (Perak) 2004, ss 35-36), Perlis (Administration of the Islamic Religion Enactment 2006 (amended 2008), ss 46-48); Sabah (Sabah Fatwa Enactment 2004, s 8), Sarawak (Islamic Religious Council of Sarawak Ordinance 2001, ss 36-7), Selangor (Administration of the Islamic Religion (Selangor) Enactment 2003, ss 46-47), and Terengganu (Administration of Islamic Religious Affairs 2001, ss 48-49).

110. The Federal Territories consists of Malaysia's capital city Kuala Lumpur, its administrative capital in Putrajaya, and the city of Labuan in East Malaysia (Borneo): FC, art 1(4).

111. Administration of Muslim Law (Federal Territories) Act 1993, ss 34 and 37(5).

112. Mufti and Fatwa (Kedah) Enactment 2008, s 8; Administration of Muslim Law (Pahang) Enactment 1991, s 36. 
they are published in the state government Gazette with the Head of State's assent. ${ }^{113}$ There is a central depository of fatwas that can be publicly accessed. ${ }^{114}$

On the contrary, there are no laws governing khutbah production in Malaysia. Despite this, the Islamic Development Department of Malaysia (JAKIM) ${ }^{115}$ is the national source of khutbahs. JAKIM was established in 1997 by a cabinet decision for a dedicated department on Islamic affairs in the Prime Minister's Office. ${ }^{116}$ Its primary function is for managing, developing, and coordinating Islamic matters among the states, and the development and harmonization of Islamic laws, ${ }^{117}$ making it Malaysia's federal religious agency. Among its many functions, mostly discursive in nature, ${ }^{118}$ JAKIM is also tasked with the dissemination of religious resources to all state religious departments, including its weekly khutbahs. ${ }^{119}$ Although JAKIM prepares khutbahs for use by state Islamic religious departments, these departments can and do produce their own khutbahs. ${ }^{120}$

\subsection{Islamic environmental law in Malaysia and its legal limits}

In Malaysia, only one environmental fatwa has been issued, and unfortunately not at the national level. The fatwa was issued by the Perlis State Fatwa Committee in February 2016. ${ }^{121}$ The fatwa titled 'Fatwa on Environmental Pollution' ('Fatwa Pencemaran Alam Sekitar') states that: ${ }^{122}$

113. This is provided as a procedure in all state enactments on the administration of Islamic law, and the criminal offence of violating a fatwa is a fixture of state Islamic criminal enactments.

114. Jabatan Kemajuan Islam Malaysia, 'e-SMAF: Sumber Maklumat al-Ahkam al-Fiqhiyyah' (JAKIM) <http://e-smaf.islam.gov.my/e-smaf/index.php/main/mainv1/fatwa/3> accessed 5 August 2020.

115. This is the acronym for its name in Malay: 'Jabatan Kemajuan Islam Malaysia'.

116. G25, 'Administration of Matters Pertaining to Islam' (n 105) 128; JAKIM, 'Jakim Berperlembagaan' (n 103).

117. Ibid, 129-32.

118. The majority of JAKIM's functions deal with protecting the mainstream Islamic doctrine as practiced in Malaysia from heresy and deviation.

119. Jabatan Kemajuan Islam Malaysia, 'e-Khutbah' (JAKIM) <www.islam.gov.my/en/e-khutbah> accessed 5 August 2020.

120. For example, among others, Jabatan Hal Ehwal Agama Terengganu, 'Laman Web EKhutbah Negeri Terengganu' (JHEAT) <http://ekhutbah.terengganu.gov.my/> accessed 4 August 2020; Jabatan Agama Islam Negeri Johor, 'eKhutbah' (JAINJ) <https://jainj.johor. gov.my/perkhidmatan/ekhutbah/> accessed 5 August 2020; Jabatan Agama Islam Selangor, 'Khutbah (English)' (JAIS) <https://e-masjid.jais.gov.my/index.php/ekhutbah/eng> accessed 5 August 2020.

121. Rashvinjeet S Bedi, 'Perlis issues a fatwa on environmental pollution' The Star (Kuala Lumpur, 1 March 2016) <www.thestar.com.my/news/nation/2016/03/01/perlis-issues-a-fatwaon-environmental-pollution/ $>$ accessed 5 August 2020; 'Perlis Fatwa Committee bans act of polluting environment' Malay Mail (Kuala Lumpur, 1 March 2016) <www.malaymail.com/ news/malaysia/2016/03/01/perlis-fatwa-committee-bans-act-of-polluting-environment/ 1071077> accessed 5 August 2020; Clean Malaysia, 'Muftis in Perlis Issue a Fatwa Against Pollution' (Clean Malaysia, 2 March 2016) <https://cleanmalaysia.com/2016/03/02/muftis-inperlis-issue-a-fatwa-against-pollution/> accessed 5 August 2020.

122. Jawatankuasa Fatwa Negeri Perlis, 'Fatwa Pencemaran Alam Sekitar [Fatwa on Environmental Pollution]' (in Malay) (e-SMAF: Sumber Maklumat al-Ahkam al-Fiqhiyyah, 19 February 2016) <http://e-smaf.islam.gov.my/e-smaf/fatwa/fatwa/find/pr/15481> accessed 5 August 2020. 
Islam is a religion that protects the well-being of humans and nature. The purpose of the syariah itself is to uphold what is good ('maslahah') and avoid harm ('mafsadah'). Thus, the Perlis State Fatwa Committee states that:

1. Any act that pollutes the environment and physically impacts human beings, animals, and plants are prohibited ('haram'), unless there is a greater good ('maslahah muktabar') in its commission or its commission prevents apparent harms.

2. Every Muslim must refrain from engaging in any activity that can cause environmental pollution that destroys life and directly disrupts ecosystems. Any effort to care for the environment is encouraged by the religion and is an act of piety ('amalan soleh').

With regard to khutbahs, JAKIM released nine environmental khutbahs between 2016 and 2019. These are exclusively produced in the Malay language.

Table 2 JAKIM environmental khutbahs, 2016-2019

No. Date (Gregorian/Islamic) Title

1. 5 August $2016 / 2$ Zulkaedah 1437

Hargai Diri Dengan Menghargai Alam (Valuing Oneself by Valuing the Environment)

2. 20 October 2016 / 20 Muharram 1438 Tanggungjawab Bersama Melestarikan Alam Sekitar (Collective Responsibility in Preserving the Environment)

3. 2 June 2017 / 7 Ramadhan 1438

Puasa dan Kelestarian Alam (The Fast and Environmental Preservation)

4. 3 August 2018 / 21 Zulkaedah 1439

5. 9 November 2018 / 1 Rabiulawwal 1440

Tanggungjawab Pemeliharaan Alam Sekitar (The Responsibility of Caring for the Environment)

Persekitaran Lestari Masyarakat Harmoni (Preserved Environment, Harmonious Society)

6. 16 November 2018 / 8 Rabiulawwal 1440

Rasulullah s.a.w.: Rahmat Ke Seluruh Alam (God's Messenger: A Mercy to All of Creation)

7. 14 December 2018 / 6 Rabiulakhir 1440

8. 1 March 2019 / 23 Jamadilakhir 1440

Islam: Agama Rahmat (Islam: Religion of Mercy)

Kelestarian Alam Amanah Allah (Environmental Sustainability as God's Trust)

9. 22 November 2019 / 25 Rabiulawwal 1441

Alam Dipelihara, Waspada Bencana (Care for the Environment, Prevent Disasters)

Most state Islamic religious departments (excluding the Federal Territories) have also produced environmental khutbahs, totalling 19 khutbahs. Note, however, that this number is not representative of hundreds of environmental khutbahs that are not uploaded online. For example, while Kelantan's Department for Islamic Affairs and Malay Custom has uploaded khutbahs dating back to 2011, most other state Islamic departments like that of Johor, Sabah, and Terengganu only began doing so in 2018. Therefore, the numbers here only reflect khutbahs that are readily accessible online. 
Table 3 List of environmental khutbahs published by Malaysian State Islamic Religious Departments

\begin{tabular}{lll}
\hline No. & State (in alphabetical order) & No. of environmental khutbahs and year(s) published \\
\hline 1. & Johor & $1(2018)$ \\
2. & Kedah & $1(2018)$ \\
3. Kelantan & $6(2011,2012,2013,2014,2019)$ \\
4. & Melaka & $1(2020)$ \\
5. Negeri Sembilan & n.a.* \\
6. Pahang & $1(2020)$ \\
7. Perlis & n.a.* \\
8. Pulau Pinang & $1(2020)$ \\
9. Sabah & $1(2018)$ \\
10. Sarawak & $2(2018,2019)$ \\
11. Selangor & $2(2014,2019)$ \\
12. & $3(2018,2019)$ \\
\hline
\end{tabular}

*Webpage of department cannot be accessed.

**No environmental khutbahs found.

Interestingly, JAKIM's 20 October 2016 khutbah, as well as several state-level khutbahs, were released in celebration of Malaysia's National Environment Day. It calls for, among others, the Muslim community to 'work together and collaborate in efforts to bring prosperity to the earth [and] take what is provided by the earth sustainably and without wastage so that they can be enjoyed by future generations'. ${ }^{123}$ This demonstrates the use of the khutbah in Malaysia to implement Islamic environmental law while tying it to national events to bolster their relevance.

\section{ISLAMIC ENVIRONMENTAL LAW-IN-ACTION: THE CASE OF INDONESIA}

\subsection{Fatwa and Khutbah in Indonesian law}

Indonesia is the most populous Muslim country in the world, accounting for about 13 percent of Muslims globally. ${ }^{124}$ Constitutionally, Islam is not recognized as the state religion; although it regards religious belief - specifically, belief in One Almighty God - as a core national tenet. ${ }^{125}$ Its infamous 'Blasphemy Law' includes Islam in its list of state-sanctioned religions; ${ }^{126}$ and generally, the Islamic religion

123. Jabatan Kemajuan Islam Malaysia, 'Tanggungjawab Bersama Melestarikan Alam Sekitar [Collective Responsibility in Preserving the Environment]' [in Malay] (JAKIM, 20 October 2016) <www.islam.gov.my/images/eKhutbah/Tanggungjawab_Bersama_Melestarikan_Alam_ Sekitar_-_Rumi.docx $>$ accessed 5 August 2020.

124. Pew Research Centre's Forum for Religion and Public Life, 'Mapping the Global Muslim Population: A Report on the Size and Distribution of the World's Muslim Population' (Pew Research Centre, October 2009) 5 <www.pewresearch.org/wp-content/uploads/sites/7/2009/ 10/Muslimpopulation.pdf $>$ accessed 29 July 2020.

125. Constitution of Indonesia, Preamble.

126. Penetapan Presiden Republik Indonesia No. 1/PNPS/1965 tentang Pencegahan Penyalahgunaan Dan/Atau Penodaan Agama [Presidential Decree No. 1/PNPS/1965 on the Prevention of Misuse and the Insulting of a Religion] [in Indonesian], art 1. 
plays an integral role in Indonesian politics. ${ }^{127}$ The operation of Islamic law in Indonesia is governed by two sources: the Kompilasi Hukum Islam (KHI) ${ }^{128}$ and the Law of Religious Judicature 1989. ${ }^{129}$ The KHI is a collection of three books on Muslim personal law: Book I deals with matrimony, Book II deals with succession, and Book III deals with trusts (wakaf). The Law of Religious Judicature 1989 establishes Shari a courts ${ }^{130}$ and defines the scope of their jurisdiction (i.e., personal and economic law). ${ }^{131}$ Despite these, there are no laws on the management of the Islamic religion generally, and thus, fatwa and khutbah production have no basis in the law.

Indonesian Islam is more prominently defined by mass Islamic organizations than the state's regulation of it; this explains why fatwa and khutbah production are the domain of non-state actors. ${ }^{132}$ The most important of these organization is the Ulama Council of Indonesian (MUI) ${ }^{133}$ which was established in 1975 by thenPresident Suharto as a pan-Indonesian platform for Islamic scholars to consult, collaborate, and cooperate. ${ }^{134}$ Although MUI is a non-state actor, its primary function is that of a national religious authority: providing assistance to the Indonesian government and its citizens on religious matters. ${ }^{135} \mathrm{~A}$ major way this is done is the issuance of 'collective' national and provincial-level fatwas. ${ }^{136}$ These fatwas are non-binding and do not in any way influence state policies, ${ }^{137}$ but in MUI's early years they have been used by the state to legitimize controversial policy positions. ${ }^{138}$ Similarly, they have been used by hard-line Islamist groups to challenge state policies and fellow

127. See MB Hooker, Indonesian Islam: Social Change Through Contemporary Fatwa (University of Hawaii Press, 2003) 1-46.

128. The KHI - or 'Compilation of the Islamic Laws of Indonesia' - was an informal source of Islamic law in Indonesia until its legal recognition by Instruksi Presiden Nomor 1 Tahun 1991 tentang Penyebarluasan Kompilasi Hukum Islam [Presidential Instruction No. 1 of 1991 concerning the Dissemination of the Compilation of Islamic Laws] [in Indonesian].

129. Undang-undang Nomor 7 Tahun 1989 tentang Peradilan Agama [Law No. 7 of 1989 on Religious Judicature] [in Indonesian].

130. Ibid, art 5.

131. Ibid, art 49; Salim Arskal, Contemporary Islamic Law in Indonesia: Sharia and Legal Pluralism (Edinburgh University Press, 2015) 33.

132. Kevin W Fogg, 'Reinforcing Charisma in the Bureaucratisation of Indonesian Islamic Organisations' (2018) 37 Journal of Current Southeast Asian Affairs 117, 118.

133. MUI is the acronym for the organization's name in Indonesian: Majelis Ulama Indonesia. 134. Majelis Ulama Indonesia, 'Sejarah MUI [History of the MUI]' [in Indonesian] (MUI) $<$ https://mui.or.id/sejarah-mui/> accessed 15 November 2018.

135. See Jan M Otto, 'Sharia and National Law in Indonesia' in Jan M Otto (ed), Sharia Incorporated: A Comparative Overview of the Legal Systems of Twelve Muslim Countries in Past and Present (Leiden University Press, 2010) 447.

136. Nico JG Kaptein, 'The Voice of the "Ulamâ": Fatwas and Religious Authority in Indonesia' (2004) 125 Archives De Sciences Sociales Des Religions 115, 120.

137. Hooker (n 67) 26-31.

138. See Piers Gillespie, 'Current Issues in Indonesian Islam: Analysing the 2005 Council of Indonesian Ulama Fatwa No. 7 Opposing Pluralism, Liberalism and Secularism' (2007) 18 Journal of Islamic Studies 202, 203; Mohamad Abdun Nasir and Asnawi, 'The Majelis Ulama's Fatwa on Abortion in Contemporary Indonesia' (2011) 101 The Muslim World 33, 34; Mu'nim Sirry, 'Fatwas and their Controversy: The Case of the Council of Indonesian Ulama (MUI)' (2013) 44 Journal of Southeast Asian Studies 100, 101-102; Ahmad Najib Burhani, 'Treating Minorities with Fatwas: A Study of the Ahmadiyyah Community in Indonesia' (2014) 8 Contemporary Islam 285; Moch Nur Ichwan, "Ulamā”, State and Politics: Majelis Ulama Indonesia After Suharto' (2005) 12 Islamic Law \& Society 45. 
citizens believed to be harmful to the religion - oftentimes sparking violence. ${ }^{139}$ Nevertheless, on a more positive note, this same mechanism has produced collective fatwas on environmental protection. ${ }^{140}$

Where khutbahs are concerned, MUI does not hold a similar monopoly of influence. Indonesia 'has its own vibrant khutbah publishing industry' ${ }^{141}$ producing khutbah 'compilations'. These books compile khutbahs on specific topics or themes, ranging from, among others, political and familial leadership, the role of women in Islam, inter-religious interactions, and the relationship between science and religion. They may also contain khutbahs for specific festivities and seasons such as Ramadan, Indonesia's Independence Day, Eid and Prophet Muhammad's birthday. ${ }^{142}$ Notwithstanding compilations published by independent scholars, ${ }^{143}$ the article focuses on compilations published by MUI.

\subsection{Indonesia's environmental Fiqh}

Over the past few decades, a uniquely Indonesian Islamic environmental jurisprudence or fiqh al-bi ${ }^{\prime}$ ah has developed. ${ }^{144}$ This is a product of rapid socio-political changes in late-1990s and early-2000s Indonesia when fatwas were used to support social and democratic change. ${ }^{145}$ Consequently, pressing environmental issues became a subject of fatwas, and to date, MUI has issued six collective fatwas concerning the environment:

- Fatwa No. 128/MUI-KS/XII/2006 on Forest Fires and Smog (Kalimantan). ${ }^{146}$

- Fatwa No. 22 of 2011 on Environmentally Friendly Mining Practices. ${ }^{147}$

- Fatwa No. 4 of 2014 on Conservation of Endangered Species for the Preservation of Ecosystem Balance. ${ }^{148}$

139. See Luthfie Assyaukanie, 'Fatwa and Violence in Indonesia' (2009) 11 Journal of Religion \& Society 1.

140. See Section 5.2 below.

141. Hooker (n 67) 129.

142. Ibid 132-73.

143. Ibid 174-203. Hooker referred exclusively to privately published khutbah compilations produced by independent scholars in his study, but expertly laid out an overview of the contents of these compilations.

144. Gade (n 8) 163-65.

145. Ibid, 162 .

146. Majelis Ulama Indonesia Wilayah IV Kalimantan, Fatwa Nomor 128/MUI-KS/XII/2006 Tentang Pembakaran Hutan dan Kabut Asap [Fatwa No. 128/MUI-KS/XII/2006 on Forest Fires and Smog] [in Indonesian] (2006) <http://sipongi.menlhk.go.id/cms/images/files/10246. pdf $>$ accessed 5 August 2020.

147. Majelis Ulama Indonesia, Fatwa Nomor 22 Tahun 2011 Tentang Pertambangan Ramah Lingkungan [Fatwa No. 22 of 2011 on Environmentally-Friendly Mining Practices] [in Indonesian] (2011), <http://mui.or.id/wp-content/uploads/files/fatwa/No.-22-Pertambangan-RamahLingkungan_final.pdf $>$ accessed 5 August 2020.

148. Fatwa Nomor 4 Tahun 2014 Tentang Pelestarian Satwa Langka Untuk Menjaga Keseimbangan Ekosistem [Fatwa No. 4 of 2014 on the Conservation of Endangered Species for the Preservation of Ecosystem Balance] [in Indonesian] (2014) <http://mui.or.id/wp-content/ uploads/files/fatwa/Pelestarian-Satwa-Langka-utk-Menjaga-Keseimbangan-Ekosistem.pdf> accessed 5 August 2020. 
- Fatwa No. 41 of 2014 on Waste Management for the Prevention of Environmental Degradation. ${ }^{149}$

- Fatwa No. 001/MUNAS-IX/MUI/2015 on the Utilization of Zakat Wealth, Infaq, Sadaqah, and Waqf for the Construction of Clean Water and Sanitation Facilities for Communities. ${ }^{150}$

- Fatwa No. 30 of 2016 regarding the Law on the Burning of Forests and Land, and the Control Thereof. ${ }^{151}$

Although these fatwas are non-binding and unenforceable in the Shari a courts, ${ }^{152}$ they are still informally 'enforced'. MUI, with the aid of international non-governmental organizations (NGO) such as Conservation International and World Wildlife Fund, implements the contents of these fatwas through its 'sosialisasi fatwa' programme. The initiative involves follow-up action applying the fatwas' rulings in localities. This is done to educate the masses on the contents of the fatwas and support their translation into practical measures in local communities. Khutbahs form part of MUI's education efforts considering that mosques are central to communities' religious life and education. ${ }^{153}$ Thus far, MUI has published four khutbah compilations that altogether contain 67 khutbahs. Furthermore, each of these books are published to disseminate the contents of four different fatwas.

\section{Table 4 MUI Khutbah Compilations}

\begin{tabular}{|c|c|c|c|}
\hline No. & Title of Compilation & Fatwa Implemented & $\begin{array}{c}\text { No. of } \\
\text { Khutbahs }\end{array}$ \\
\hline 1. & $\begin{array}{l}\text { Hifdzul Biah - A Collection of } \\
\text { Khutbah for Friday and Eid Prayers: } \\
\text { Protection and Management of the } \\
\text { Environment and Natural Resources }\end{array}$ & $\begin{array}{l}\text { Fatwa No. } 22 \text { of } 2011 \text { on } \\
\text { Environmentally Friendly } \\
\text { Mining Practices }\end{array}$ & 30 \\
\hline
\end{tabular}

(continued)

149. Fatwa Nomor 41 Tahun 2014 Tentang Pengelolaan Sampah Untuk Mencegah Kerusakan Lingkungan [Fatwa No. 41 of 2014 on Waste Management for the Prevention of Environmental Degradation] [in Indonesian] (2014) <http://mui.or.id/wp-content/uploads/files/fatwa/Pengelo laan-Sampah-utk-Mencegah-Kerusakan-Lingkungan.pdf> accessed 5 August 2020.

150. Fatwa Nomor 001/MUNAS-IX/MUI/2015 Tentang Pendayagunaan Harta Zakat, Infaq, Sedekah and Wakaf Untuk Pembangunan Sarana Air Bersih dan Sanitasi Bagi Masyarakat [Fatwa No. 001/MUNAS-IX/MUI/2015 on the Utilization of Zakat Wealth, Infaq, Sadaqah, and Waqf for the Construction of Clean Water and Sanitation Facilities for Communities] [in Indonesian] (2015) <http://mui-lplhsda.org/wp-content/uploads/2016/11/Fatwa-001-ZISWAFuntuk-Air-Sanitasi-MUI.pdf $>$ accessed 5 August 2020.

151. Fatwa No. 30 of 2016 Regarding the Law on the Burning of Forests and Land and the Control Thereof (2014) <https://mui-lplhsda.org/wp-content/uploads/2016/08/FATWA-KARHUTLA-versi-English.pdf> accessed 5 August 2020.

152. Arskal (n 131) 33.

153. See Section 2.2 above; Eka Rahmat Hidayat, 'EcoMasjid: The First Milestone of Sustainable Mosque in Indonesia' (2018) 5 Journal of Islamic Architecture 20, 20 ('to spread the idea of Muslims [getting involved] in promoting environmental conservation, [begin] from ... [their] worship place.').

154. Lembaga Pemuliaan Lingkungan Hidup dan Sumber Daya Alam, Buku Khutbah Hifdzul Biah: Perlindungan dan Pengelolaan Lingkungan Hidup dan Sumber Daya Alam [Hifdzul Biah - A Collection of Khutbah for Friday and Eid Prayers: Protection and Management of the Environment and Natural Resources] [in Indonesian] (MUI, 2012). 
Table 4 MUI Khutbah Compilations (continued)

\begin{tabular}{|c|c|c|c|}
\hline No. & Title of Compilation & Fatwa Implemented & $\begin{array}{c}\text { No. of } \\
\text { Khutbahs }\end{array}$ \\
\hline 2. & $\begin{array}{l}\text { Friday Prayers Khutbah: Water, } \\
\text { Cleanliness, Sanitation, and } \\
\text { Environmental Health according to } \\
\text { Islam }{ }^{155}\end{array}$ & $\begin{array}{l}\text { Fatwa No. 001/MUNAS-IX/MUI/ } \\
2015 \text { on the Utilization of Zakat } \\
\text { Wealth, Infaq, Sadaqah, and } \\
\text { Waqf for the Construction of } \\
\text { Clean Water and Sanitation } \\
\text { Facilities for Communities }\end{array}$ & 15 \\
\hline 3. & $\begin{array}{l}\text { Friday Prayers Khutbah: Conservation } \\
\text { of Endangered Species for } \\
\text { Ecological Balance }\end{array}$ & $\begin{array}{l}\text { Fatwa No. } 4 \text { of } 2014 \text { on Conservation } \\
\text { of Endangered Species for the } \\
\text { Preservation of Ecosystem Balance }\end{array}$ & 12 \\
\hline 4. & $\begin{array}{l}\text { Friday Prayers Khutbah: Conservation } \\
\text { and Restoration of Peatlands }{ }^{157}\end{array}$ & $\begin{array}{l}\text { Fatwa No. } 30 \text { of } 2016 \text { regarding the } \\
\text { Law on the Burning of Forests and } \\
\text { Land, and the Control Thereof }\end{array}$ & 10 \\
\hline
\end{tabular}

In addition to khutbahs for Friday prayers, the Board also publishes guidebooks for practical implementation. These are produced to guide the operation of religious boarding schools (pesantren) towards becoming eco-friendly, and the capacitybuilding of preachers and local volunteers who engage in environmental advocacy and render technical assistance in communities as part of sosialisasi fatwa. The latter mobilization or 'caderization' of volunteers from the MUI membership is deemed integral to sosialisasi fatwa's objective for 'community empowerment' toward environmental sustainability. ${ }^{158}$

Table 5 MUI fatwas and their accompanying guidebooks

\begin{tabular}{|c|c|}
\hline Fatwa & Guidebook(s) \\
\hline $\begin{array}{l}\text { Fatwa No. } 4 \text { of } 2014 \text { on the Conservation } \\
\text { of Endangered Species for the Preservation } \\
\text { of Ecosystem Balance }\end{array}$ & $\begin{array}{l}\text { Conservation of Endangered Species for } \\
\text { Ecosystem Balance: The Administration of } \\
\text { the Socialization of MUI's Fatwa No. } 4 \text { of } \\
2014 \text { on Biodiversity Conservation for the } \\
\text { Preservation of Ecosystem Balance }{ }^{159}\end{array}$ \\
\hline
\end{tabular}

155. Lembaga Pemuliaan Lingkungan Hidup dan Sumber Daya Alam, Buku Khutbah Jum'at Air, Kebersihan, Sanitasi dan Kesehatan Lingkungan menurut Agama Islam [Friday Prayers Khutbah: Water, Cleanliness, Sanitation, and Environmental Health according to Islam] [in Indonesian] (MUI, 2016).

156. Lembaga Pemuliaan Lingkungan Hidup dan Sumber Daya Alam, Buku Khutbah Jum'at: Pelestarian Satwa Langka Untuk Menjaga Keseimbangan Ekosistem [Friday Prayers Khutbah: Conservation of Endangered Species for Ecological Balance] [in Indonesian] (MUI, 2017).

157. Badan Restorasi Gambut, Khutbah Jumat Pelestarian dan Restorasi Lahan Gambut [Friday Prayers Khutbah: Conservation and Restoration of Peatlands] [in Indonesian] (MUI, 2018). 158. Anna M Gade, 'Tradition and Sentiment in Indonesian Environmental Islam' (2012) 16 Worldviews: Global Religions, Culture and Ecology 263, 274.

159. Lembaga Pemuliaan Lingkungan Hidup dan Sumber Daya Alam, Pelestarian Satwa Langka untuk Keseimbangan Ekosistem: Penuntun Sosialisasi Fatwa MUI No. 4, 2014 Tentang Pelestarian Satwa Langka Untuk Menjaga Keseimbangan Ekosistem [Conservation of 
Table 5 MUI fatwas and their accompanying guidebooks (continued)

\begin{tabular}{|c|c|}
\hline Fatwa & Guidebook(s) \\
\hline $\begin{array}{l}\text { Fatwa No. 001/MUNAS-IX/MUI/2015 on } \\
\text { the Utilization of Zakat Wealth, Infaq, } \\
\text { Sedekah, and Wakaf for the Construction } \\
\text { of Clean Water and Sanitation Facilities } \\
\text { for Communities }\end{array}$ & $\begin{array}{l}\text { Water, Hygiene, Sanitation and Environmental } \\
\text { Health in Islam } \\
\text { Training Materials for Preachers for Sanitation: } \\
\text { Guide to Community- Based Sanitation }{ }^{161} \\
\text { Learning Journey of the Preachers for Sanitation } \\
\text { Programme: Rallying and Controlling } \\
\text { Community-Based Sanitation }{ }^{162}\end{array}$ \\
\hline $\begin{array}{l}\text { Fatwa No. } 30 \text { of } 2016 \text { regarding the Law } \\
\text { on the Burning of Forests and Land, and } \\
\text { the Control Thereof }\end{array}$ & $\begin{array}{l}\text { Module for the Capacity-Building of Preachers } \\
\text { for Peatland Restoration: Implementation of } \\
\text { MUI's Fatwa No. } 30 \text { of } 2016^{163}\end{array}$ \\
\hline
\end{tabular}

The most significant result of sosialisasi fatwa is the 'EcoMasjid' project ${ }^{164}$ that has begun renovating Indonesian mosques, in phases, towards becoming eco-friendly. ${ }^{165}$ 'Renovation' includes the capacity-building of mosque managers, especially training them in waste and water management. ${ }^{166}$ Upon completion of these training

Endangered Species for Ecosystem Balance: The Administration of the Socialization of MUI's Fatwa No. 4 of 2014 on Biodiversity Conservation for the Preservation of Ecosystem Balance] [in Indonesian] (MUI, 2017).

160. Lembaga Pemuliaan Lingkungan Hidup dan Sumber Daya Alam, Air, Kebersihan, Sanitasi dan Kesehatan Lingkungan menurut Agama Islam [Water, Hygiene, Sanitation and Environmental Health in Islam] [in Indonesian] (MUI, 2015).

161. Lembaga Pemuliaan Lingkungan Hidup dan Sumber Daya Alam, Materi Pelatihan Dai Sanitasi: Pendampingan Sanitasi Total Berbasis Masyarakat [Training Materials for Preachers for Sanitation: Guide to Community-Based Sanitation] [in Indonesian] (MUI, 2017).

162. Lembaga Pemuliaan Lingkungan Hidup dan Sumber Daya Alam, Kisah Pembelajaran Perjalanan Program Dai Sanitasi: Menyeru dan Mengawal Sanitasi Total Berbasis Masyarakat [Learning Journey of the Preachers for Sanitation Programme: Rallying and Controlling Community-Based Sanitation] [in Indonesian] (MUI, 2017).

163. Lembaga Pemuliaan Lingkungan Hidup dan Sumber Daya Alam, Modul Peningkatan Kapasitas Da'i Restorasi Gambut: Implementasi Fatwa MUI No. 30/2016 [Module for the Capacity-Building of Preachers for Peatland Restoration: Implementation of MUI's Fatwa No. 30 of 2016] [in Indonesian] (MUI, 2018).

164. Hayu Prabowo, 'Gerakan Nasional Pemuliaan Lingkungan Hidup Berbasis Masjid [A Mosque-Centric National Movement for the Sacralization of the Environment]' [in Indonesian] (MUI-LPLHSDA, 27 June 2016) <https://mui-lplhsda.org/ecomasjid/> accessed 5 August 2020.

165. Hayu Prabowo, 'Peningkatan Kualitas Sarana Dan Prasarana Ibadah Melalui Program Masjid Ramah Lingkungan (EcoMasjid) [Renovations to the Quality of the Site and Facilities of Places of Worship Through the Eco-Friendly Mosque Project (EcoMasjid)]' [in Indonesian] (MUI-LPLHSDA, 19 February 2016) <https://mui-lplhsda.org/peningkatan-kualitas-sarana-danprasarana-ibadah-melalui-program-ecomasjid/> accessed 5 August 2020.

166. Hayu Prabowo, 'Pelatihan Pengelolaan Masjid Ramah Lingkungan [Training for the Management of Environmentally-Friendly Mosques]' [in Indonesian] (MUI-LPLHSDA, 6 November 2019) <http://ecomasjid.id/post/pelatihan-pengelolaan-masjid-ramah-lingkungan> accessed 5 August 2020; Hayu Prabowo, 'Pelatihan Pengurangan Sampah Makanan Pada Pengurus Masjid [Training on the Reduction of Food Wastes for Mosque Managers]' [in Indonesian] (MUI-LPLHSDA, 13 November 2019) <http://ecomasjid.id/post/pelatihan-pengurangansampah-makanan-pada-pengurus-masjid $>$ accessed 5 August 2020. This includes the production of bio-fuels from bio-wastes produced by mosques. 
programmes, a mosque is certified as an 'EcoMasjid'. ${ }^{167}$ Thus far, 139 mosques around Indonesia are participating in this project. ${ }^{168}$ Therefore, from an MUI fatwa, to a mosque officer creating biofuels from the mosque's food waste, sosialisasi fatwa reflects Islamic environmental law-in-action: a non-state environmental management system that relies on bottom-up, mosque-centric, and volunteer-supported implementation of Islamic environmental law in the grassroots.

\section{INSIGHTS FROM CASE STUDIES ON THE LIMITATIONS OF IMPLEMENTING ISLAMIC ENVIRONMENTAL LAW THROUGH NON-BINDING INSTRUMENTS}

The three case studies above reveal much about the extent to which the implementation of Islamic environmental law has been pursued by their respective religious authorities. Based on the article's definition of 'implementation' - i.e., establishing norms and subsequently putting them into practice - the production of fatwas and khutbahs alone is inchoate. The implementation of Islamic environmental law through non-binding instruments relies on whether the local legal and political contexts help make implementation not just possible, but also able to be seen as authoritative and legitimate sources of norms. This depends on the relationship between the state and 'religion' as a socio-political institution in a particular jurisdiction. Secondly, there is also reliance on the pursuit of follow-up actions post-fatwa and post-khutbah to put the laws they establish into practice. These two factors manifest differently in our three case studies, and as a result, their impact on the implementation of Islamic environmental law respectively differs. Regardless, they are both vital to ensuring that these non-binding instruments achieve their social control objectives.

\subsection{Religion-state relations and their impact on implementation}

In our case studies, like most Asian countries, the state never truly 'secularized' - i.e., religion still influences constitutional law, politics, and culture. ${ }^{169}$ In Southeast Asia alone, religious movements such as the Buddhist Sangha in Thailand and Myanmar, and Muslim organizations and parties in Malaysia and Indonesia actively participate in legal and political discourse. ${ }^{170}$ It is therefore generally observed that the relationship between the state and 'religion' (both doctrinally and institutionally) in our case studies determines the limits to implementing Islamic environmental law and the authority and legitimacy of fatwas, khutbahs, and non-binding religio-legal instruments in general.

167. EcoMasjid, 'Sertifikasi EcoMasjid [EcoMasjid Certification]' [in Indonesian] (MUILPLHSDA) <http://ecomasjid.id/self-assesment> accessed 5 August 2020.

168. This number is as of 29 July 2020. EcoMasjid, 'Fasilitas [Facilities]' [in Indonesian] (MUI-LPLHSDA) <http://ecomasjid.id/\#fasilitas> accessed 5 August 2020.

169. See Arif A Jamal, Jaclyn L Neo, and Daniel PS Goh, Regulating Religion in Asia: Norms, Modes, and Challenges (Cambridge University Press, 2019).

170. See Dian AH Shah, Constitutions, Religion and Politics in Asia: Indonesia, Malaysia and Sri Lanka (Cambridge University Press, 2017). 


\subsubsection{Singapore}

MUIS fatwas and khutbahs enjoy authority and legitimacy because it is the national Islamic authority and participates in the national discourse concerning state policies. From a constitutional perspective, MUIS was created to install legal and policy infrastructures for administering Muslim affairs, and its functions such as fatwa-production are provided by a statute, i.e., AMLA. ${ }^{171}$ This places them in proximity of the state both existentially and functionally, implying an assumption that they are essentially part of the bureaucracy and cannot make decisions independently. ${ }^{172}$ While this is peculiar for a modern secular state like Singapore, MUIS' existence is also attributable to the state's practice of accommodative secularism, ${ }^{173}$ where the Singapore government is 'antitheocratic, [but] not anti-religious', and religion is recognized as a 'constructive social force' and 'a positive factor in Singapore society'. ${ }^{174}$ This in turn allows MUIS to participate in national discourse through its fatwas. Their fatwas have been issued on matters of national and ethical importance such as debates revolving around stem cell research in 2001, ${ }^{175}$ the Human Organ Transplant Act in 2007, ${ }^{176}$ and Singapore's social security institution - the Central Provident Fund (CPF) Board. ${ }^{177}$ Including the two 'water price hike' khutbahs referred to earlier, ${ }^{178}$ it is suggested that the Council is extremely responsive to the needs of Singaporean Muslims in providing guidance on navigating state policies. With these in mind, Singapore's legal and political contexts apparently permit and support the implementation of Islamic environmental law.

\subsubsection{Malaysia}

The nature of the Malaysian state - whether it is Islamic or secular or somewhere in between - remains a point of contention to this day. ${ }^{179}$ This, however, does not stymie the influence of religion in Malaysian constitutional and political culture. ${ }^{180}$ This interestingly includes its influence on environmental policy understood

171. See Section 3.1 above.

172. cf Afif Pasuni, 'Negotiating Statist Islam: Fatwa and State Policy in Singapore' (2018) 37 Journal of Current Southeast Asian Affairs 57, 60.

173. Nappali Peter Williams v Institute of Technical Education [1999] 2 SLR(R) 529 at [28]. Also called 'secularism with a soul': Singapore Parliamentary Debates, Official Report (17 November 2008) vol 84 at col 741 (Zainul Abidin Rasheed, Senior Minister of State for Foreign Affairs).

174. Li-Ann Thio, A Treatise on Singapore Constitutional Law (Academy Publishing, 2012) 210.

175. MUIS Fatwa on Stem Cell Research (issued on 22 November 2001) <www.muis.gov.sg/ officeofthemufti/Fatwa/English-Stem-Cell-Research> accessed 5 August 2020.

176. MUIS Fatwa on Organ Transplants in Singapore (issued on 17 July 2007) <www.muis. gov.sg/officeofthemufti/Fatwa/English-HOTA> accessed 5 August 2020.

177. MUIS Fatwa on CPF Nomination (issued on 3 August 2010) <www.muis.gov.sg/officeofthe mufti/Fatwa/CPF-Nomination> accessed 5 August 2020.

178. See Section 3.2 above.

179. See Joseph M Fernando, 'The Position of Islam in the Constitution of Malaysia' (2006) 37 Journal of Southeast Asian Studies 249; Mohamed Azam Mohamed Adil, 'Is Malaysia a Secular State?' New Straits Times (Kuala Lumpur, 28 December 2018) <www.nst.com.my/opinion/ columnists/2018/12/444567/malaysia-secular-state> accessed 5 August 2020.

180. See generally Michael D Barr and Anantha R Govindasamy, 'The Islamisation of Malaysia: Religious Nationalism in the Service of Ethnonationalism' (2010) 64 Australian Journal of International Affairs 293. 
broadly. In 2004, for example, the Prime Minister Abdullah Badawi's administration promoted the 'Islam Hadhari' ideology where 'policies and strategies will be formulated and reviewed to represent the best interests of society' based on ten principles of Islamic governance; and one principle was 'environmental protection'. ${ }^{181}$ Another example is the integration of Islamic religious values in land-use planning through the 'Total Planning and Development Doctrine' (Doktrin Perancangan dan Pembangunan Sejagat) adopted by the Town and Country Planning Department of the Ministry of Housing and Local Government. ${ }^{182}$

Religion in Malaysian politics, however, is a controversial subject. Despite the universality of the environmental cause, extending the reach of Islamic law to environmental protection in Malaysia may have political repercussions. Recent 'extension' attempts - albeit for non-environmental reasons - saw backlash from local civil society. ${ }^{183}$ Moreover, the cases concerning religious freedom before the Malaysian courts have negatively portrayed Islamic law's operation in the country. ${ }^{184}$ It is unknown whether the public interest nature of environmental protection can assuage these pre-existent tensions, hence consequences of going beyond the status quo vis-àvis Islamic environmental norm-implementation are also unknown.

Malaysian law also hampers the implementation of Islamic environmental law. As mentioned earlier, state-level fatwas in Malaysia can be made binding by publication in the state government's Gazette. However, in reality, the law contains hidden barriers to the subsequent enforcement of an environmental fatwa before the Shari a courts. In the case of Malaysia's only environmental fatwa, section 49 of the Administration of the Islamic Religion (Perlis) Enactment 2006 makes Perlis State Fatwa Committee's fatwa legally-binding on all Muslims in Perlis upon publication in its state government's Gazette. ${ }^{185}$ This was never done; but if it was to be published for the purpose of making it judicially enforceable, the occurrence of 'double jeopardy' presents a strong argument against doing so. In Malaysia, Islamic and secular criminal laws exist and are enforced separately. ${ }^{186}$ Thus, in the case of a Muslim domiciled in Perlis

181. See Prime Minister's Department, 'Ninth Malaysia Plan, 2006-2010' (Prime Minister's Department, Putrajaya, Malaysia 2006) <www.pmo.gov.my/dokumenattached/RMK/RM9_E. pdf $>$ accessed 5 August 2020.

182. The Islamic character of those values was neutralized to present a pantheistic framework to be inclusive. See Abu Bakar Abdul Majeed, 'Islam in Malaysia's Planning and Development Doctrine' in Richard Foltz et al, Islam and Ecology: A Bestowed Trust (Center for the Study of World Religions, Harvard Divinity School, 2003) 467-74.

183. See eg, Malaysian Bar, 'Malaysian Bar calls for less haste, more public consultation on Shariah Bill' (Malaysian Bar, 1 August 2018) <www.malaysianbar.org.my/bar_news/berita_ badan_peguam/malaysian_bar_calls_for_less_haste_more_public_consultation_on_shariah_bill. html?date=2018-08-01 > accessed 5 August 2020; Tan Sri Mohd Sheriff bin Mohd Kassim, 'Focus on reforms, not political Hudud' (G25, 6 June 2016) <www.g25malaysia.org/singlepost/2016/06/06/Focus-on-reforms-not-Hudud> accessed 5 August 2020.

184. See Nehaluddin Ahmad, Ahmad Masum, and Abdul Mohaimin Ayus, 'Freedom of Religion and Apostasy: The Malaysian Experience' (2016) 38 Human Rights Quarterly 736; Eugene Yapp, 'Religious Freedom in Malaysia: The church's engagement for justice and equity in the public arena' (Lausanne Global Analysis, vol 4 issue 1, January 2015) <https://www.lausanne. org/content/lga/2015-01/religious-freedom-in-malaysia> accessed 5 August 2020.

185. Administration of the Islamic Religion Enactment 2006 (amended 2008) s 49.

186. Dian AH Shah and Azizuddin Sani, 'Freedom of Religion in Malaysia: A Tangled Web of Legal, Political, and Social Issues' (2011) 36 North Carolina Journal of International Law and Commercial Regulation 647, 673-77. 
getting criminally charged for polluting a river under section 25 of Malaysia's Environmental Quality Act $1974,{ }^{187}$ they may be concurrently charged under section 39 of Perlis' Islamic Criminal Enactment 1991 for violating the environmental fatwa. ${ }^{188}$ Although records show that fatwa violations have never been tried in Shari'a courts nationwide, ${ }^{189}$ the disproportionality of punishing a polluter under two different legal systems (i.e., secular and Islamic) is unsettling.

\subsubsection{Indonesia}

As mentioned before, Islam and MUI play important roles in Indonesian law, politics and society. It is unsurprising then that MUI's role as Indonesia's informal national Islamic authority is so well-recognized to the extent that its environmental initiatives are relied upon and openly supported by the state to complement existing national regulations. ${ }^{190}$ For example, its latest fatwa, Fatwa No. 30 of 2016, was requested by the Minister for the Environment and Forestry to establish a moral basis for compliance with forestry laws and the abandoning of slash-and-burn techniques in agriculture. ${ }^{191}$ The fatwa, published in both Indonesian and English, does not only prohibit forest burning, but also provides recommendations for state and provincial governments, businesses, and the community at large. ${ }^{192}$

Also interesting is how MUI fatwas mimic the form (and perhaps consequently the 'authoritative force') of state legislation. The most obvious way this can be observed is by looking at how fatwas are titled - a striking similarity to national legislation.

Table 6 Similarity between the name format of state legislation and MUI fatwas

\begin{tabular}{ll}
\hline Format & Example \\
\hline Law No. $<$ Number $>$ of $<$ Year $>$ & Law No. 18 of 2008 on Waste Management \\
on/regarding/concerning $<$ Subject $>$ & Fatwa No. 41 of 2014 on Waste Management for \\
Fatwa No. $<$ Number $>$ of $<$ Year $>$ & the Prevention of Environmental Degradation \\
\hline on/regarding/concerning $<$ Subject $>$ & \begin{tabular}{c} 
Sulion \\
\hline
\end{tabular}
\end{tabular}

This can also be observed by how these fatwas' contents are formatted: ${ }^{193}$

[MUI fatwas are] reminiscent of the textual products of the government bureaucracy, referring to previous decisions of the MUI, government decisions, and summing up the considerations systematically, as in the promulgation of a state law; sometimes even the date from which a certain fatwa will be valid, is mentioned.

187. Environmental Quality Act 1974 (Act 127), s 25.

188. Islamic Criminal (Perlis) Enactment 1991 (amended 2007), s 39.

189. Based on the present author's own research. No quantitative research had been done prior to this.

190. Gade (n 8) 169-71.

191. Wahyu Suryana, 'MUI Keluarkan Fatwa Pembakaran Hutan Haram' Republika (Jakarta, 13 September 2016) <www.republika.co.id/berita/dunia-islam/islam-nusantara/16/09/13/ odfk3g384-mui-keluarkan-fatwa-pembakaran-hutan-haram> accessed 5 August 2020.

192. Ibid.

193. Kaptein (n 136) 121. 
Hence, while MUI fatwas are not legally binding, mimicking statutory 'packaging' to make them appear official, as well as explicit governmental support of its environmental projects, bolsters their authoritativeness and legitimacy.

This is not the case for environmental khutbahs. Khutbah delivery in Indonesia is unregulated, and neither MUI nor the Indonesian government has the power to determine what sermons are delivered in mosques. ${ }^{194}$ Mosques are free to choose the khutbahs they deliver during congregational prayers, and these tend to be what the mosque managers deem to be most important and are in their best interest at any given time. ${ }^{195}$ This implies that MUI's environmental khutbahs may, in reality, never see the light of day; defeating their purpose and undermining the social control effects intended. Nevertheless, even if the khutbahs are not delivered to mosque congregations, they are but one follow-up action in MUI's sosialisasi fatwa programme. Also, it is highly likely that MUI's environmental khutbah compilations are used as reference materials for sosialisasi fatwa's other educational avenues and the operation of EcoMasjid mosques. The programme's infrastructure for Islamic environmental law-in-action in Indonesia, therefore, differentiates the country's approach to implementing Islamic environmental norms to that in Singapore and Malaysia; that, MUI fatwas and khutbahs are not mere words on paper but are made actionable through sosialisasi.

\subsection{Follow-up action and practicing what is preached}

Implementation of Islamic environmental law is inchoate unless religious authorities pursue follow-up action and ensure what is preached is practised. Since implementing Islamic environmental law through non-binding instruments relegates enforcement of religious law to the religious community, follow-up action is necessary to normalize the actions and behaviours encouraged (or mandated) by those norms. ${ }^{196}$ Notwithstanding the factors influencing the material ability for follow-up (resources) and the willingness to do so (other political, social, economic factors that burden follow-up), follow-up action remains necessary in religious communities where nudges from religious leadership and fellow believers are vital to effecting behavioural change. ${ }^{197}$

\subsubsection{Indonesia}

For one, Indonesia's sosialisasi fatwa presents a model that can be exemplified by the Islamic agencies in Malaysia and Singapore. MUI and its member organizations involve grassroots leaders, volunteers, and preachers in bringing communities along into compliance of their fatwas' contents; framing initiatives and projects as

194. The Indonesian government generally takes a 'hands-off' approach to matters under the traditional domain of Islamic organizations, and any form of state encroachment to these organizations' independence is heavily criticized. See e.g. Alfitri, 'Religion and Constitutional Practices in Indonesia: How Far Should the State Intervene in the Administration of Islam' (2018) 13 Asian Journal of Comparative Law 389.

195. This fact was discovered through a conversation with an Indonesian legal scholar.

196. Kimin Eom et al, 'Cultural Variability in the Link Between Environmental Concern and Support for Environmental Action’ (2016) 27 Psychological Science 1331, 1335.

197. See Jesse Lee Preston, Erika Salomon, and Ryan S Ritter, 'Religious Prosociality: Personal, Cognitive, and Social Factors' in Vassilis Saroglou (ed), Religion, Personality, and Social Behavior (Psychology Press, 2014) 159. 
collective endeavours towards fulfilling key religious obligations. ${ }^{198}$ The manpower and resources expended and the initiative to collaborate with international organizations ${ }^{199}$ in sosialisasi fatwa also supports its pursuit of follow-up action such as the EcoMasjid project. Obviously, these are lacking or entirely absent in in the cases of Malaysia and Singapore.

\subsubsection{Malaysia}

In Malaysia, a sceptic may argue that sosialisasi-style follow-up is impossible because its Islamic institutions are preoccupied with other priorities - they are infamous for expending most (if not all) of their resources regulating public morality. ${ }^{200}$ However, this is not entirely true in light of recent evidence of their attempts to pursue environmental projects. On 21 October 2019, JAKIM 'in collaboration with the Selangor Islamic Religious Department and several other agencies' organized the 'Clean \& Green: Rahmah for All' event in Kuala Lumpur ${ }^{201}$ in celebration of National Environment Day. Generally, the event hopes to 'instill a culture of tolerance and mutual love in communities regardless of race and religion' as a branch of Malaysia's environmental protection ethos. ${ }^{202}$ The socio-ecological objectives of the event aside, this is the only event by JAKIM thus far. Although similar events in future remain to be seen, this may be first steps toward the actual practice of Islamic environmental law in Malaysia.

\subsubsection{Singapore}

Much less can be said about MUIS' approach to implementing Islamic environmental law since they have yet to follow up on the norms their khutbahs contain. When the Singapore government designated 2018 and 2019 as 'Year of Climate Action'203 and 'Year Towards Zero Waste' ${ }^{204}$ respectively, MUIS merely produced more environmental khutbahs in addition to pledging to adopt sustainable organizational practices. $^{205}$

198. See Linda Steg and Charles Vlek, 'Encouraging Pro-Environmental Behaviour: An Integrative Review and Research Agenda' (2009) 29 Journal of Environmental Psychology 309, 311.

199. Gade (n 8) 166.

200. See Mohd Darbi Hashim, 'Of Morality and Individualism in Malaysia' (2006) 67 Akademika 103.

201. Jabatan Kemajuan Islam Malaysia, 'Kenyataan Media JAKIM Berkenaan Program "Clean \& Green: Rahmah for All [JAKIM Media Release on 'Clean \& Green: Rahmah for All” Programme]' [in Malay] (JAKIM, 29 November 2019) <www.islam.gov.my/en/media-jakim/media-statement/ 2215-kenyataan-media-jakim-berkenaan-program-clean-green-rahmah-for-all> accessed 29 July 2020.

202. Ibid.

203. 'Singapore to declare 2018 Year of Climate Action' (Channel News Asia, 17 November 2017) $<$ www.channelnewsasia.com/news/singapore/singapore-to-declare-2018-year-of-climate-action9414346\#: :text=SINGAPORE\%3A\%20Singapore\%20will\%20designate\%202018,on\% 20Thursday\%20(Nov\%2016).> accessed 5 August 2020.

204. '2019 is Singapore's Year Towards Zero Waste', Press Release, Ministry of Environment and Water Resources (12 January 2019) <www.mewr.gov.sg/news/2019-is-singapores-yeartowards-zero-waste> accessed 5 August 2020.

205. Ministry of Environment and Water Resources, 'Pledge Gallery - Majlis Ugama Islam Singapura (MUIS)' (MEWR) <www.mewr.gov.sg/climateaction/test-gallery/majlis-ugamaislam-singapura-(muis) $>$ accessed 5 August 2020. 
This raises the question of whether MUIS is content with their current approach or there are factors preventing them from going beyond khutbahs, especially since these two years were opportune times to pursue follow-up action.

In sum, MUI leadership in Indonesia is committed to practicing what they preach and ensuring that the community follows. To a lesser extent, the Malaysian religious authorities have only recently attempted to do this; and Singapore's MUIS have not done anything.

\section{CONCLUSION}

This article has offered insights into the implementation of Islamic environmental law through the use of fatwas and khutbahs in Singapore, Malaysia, and Indonesia. It began by exploring the two main approaches to its implementation today, i.e. implementation by constitutions and by non-binding religious instruments, before going into detail on the fatwa and khutbah as part of the latter approach. It then moved into three case studies, laying down the laws that support fatwa and khutbah-production, and how these instruments were used to implement Islamic environmental law. Then, based on the case studies, the article analysed the key factors that ensures that these non-binding instruments achieve their social control objectives: these being, first, favourable legal and political climates brought about by positive religion-state relations; and, second, religious authorities ensuring that what is preached is translated into practice.

'Are there solutions to overcoming the limitations that adversely affect implementation in the specific cases of Singapore and Malaysia?' is a question for further discussion, but which ultimately rests with the religious authorities themselves. It goes beyond the scope of this article to suggest legal and policy reforms beyond calling for the recognition of the importance for these agencies to engage in critical self-assessment concerning their current approaches to implementing Islamic environmental law. They must, first and foremost, ask themselves: 'what is stopping us?'. Identifying the reasons for not pursuing follow-up actions helps the search for solutions to alleviate the doubts and burdens stopping them; or, it may motivate the crafting of creative solutions that circumvent those problems. From a legal perspective, it suffices to posit that the laws in these countries allow for fatwas and khutbahs to have actual social control effects on Muslims - and this is true for many non-environmental subjects they have had to deal with. Therefore, in this context, the law does not require reform as much as the religious agencies' approach to implementing Islamic environmental law requires reflection and revision. 